\title{
PENGETAHUAN DAN SIKAP REMAJA PUTRI DESA ALUH-ALUH BESAR RT. 04 MENGENAI COVID-19
}

\author{
Ayu Riana Sari'), Devia Lestari'1), M. Norji Arbaen ${ }^{1)}$, Odelia Bernadette Butar Butar') \\ 1)Program Studi Kesehatan Masyarakat, Fakultas Kedokteran, Universitas Lambung Mangkurat \\ Corresponding author : Ayu Riana Sari \\ E-mail : ayumumtaz89@gmail.com
}

Diterima 28 November 2021, Diterima 07 Desember 2021, Disetujui 07 Desember 2021

\begin{abstract}
ABSTRAK
Indonesia merupakan salah satu negara dengan jumlah kasus Covid-19 terkonfirmasi yang cukup tinggi. Kalimantan Selatan merupakan provinsi dengan jumlah kasus yang mengalami peningkatan. Kabupaten Banjar termasuk salah satu kabupaten dengan jumlah kasus Covid-19 yang cukup tinggi dan terus mengalami peningkatan. Kegiatan pengabdian ini dilakukan untuk melihat pengetahuan dan sikap remaja putri di Desa Aluh-Aluh Besar RT. 04 terhadap Covid-19. Subjek yang mengikuti kegiatan berjumlah 14 remaja putri. Penyelenggaraan pengabdian masyarakat ini terdiri dari 3 tahap meliputi: tahap persiapan yaitu pengumpulan kontak remaja putri serta pembuatan media, tahap pelaksanaan kegiatan pemberian pretest dan posttest serta pemberian materi, dan tahap monitoring dan evaluasi meliputi pemantauan dan pengawasan kegiatan penyuluhan serta menilai peningkatan dalam pengetahuan mengenai Covid-19. Data diperoleh dari hasil pretest dan posttest. Hasil kegiatan ini terdapat perbedaan yang signifikan antara pengetahuan remaja putri pada saat pengisian kuesioner sebelum dan sesudah penyuluhan dan ada perbedaan antara sikap remaja putri di pada saat pengisian kuesioner sebelum dan sesudah penyuluhan.
\end{abstract}

Kata Kunci: pengetahuan; sikap; covid-19

\begin{abstract}
Indonesia is one of the countries with a high number of confirmed Covid-19 cases. South Kalimantan is a province with an increasing number of cases. Banjar Regency is one of the districts with a fairly high number of Covid-19 cases and continues to increase. This service activity was carried out to see the knowledge and attitudes of young women in the Village of Aluh-Aluh Besar RT. 04 against Covid- 19. Subjects who attended lessons were 14 young women. The implementation of this community service consists of 3 stages including: stages of preparation, preparation phase the contacts of young women and making media, activity phase of presenting pretest and posttest and presenting material, and the stages of monitoring and evaluating activities and monitoring activities as well as assessing the increase in Covid-19 knowledge. Data obtained from the results of the pretest and posttest. The result of this activity is that there is a significant difference between the knowledge of young women when filling out the questionnaire before and after counseling and there is a difference between the attitudes of young women when filling out the questionnaire before and after extension.
\end{abstract}

Keywords: knowledge; attitude; covid-19

\section{PENDAHULUAN}

Dalam hal munculnya pandemi COVID19, mengakibatkan pemerintah membatasi ruang gerak dalam melakukan aktivitas yang dilakukan bersama-sama. Kegiatan tri dharma perguruan tinggi yang melibatkan banyak peserta, salah satunya adalah kegiatan Program Based Learning (PBL). Agar kegiatan dapat dijalankan secara penuh dan aktif maka hal tersebut dapat dilakukan dengan dilakukan dengan menggunakan media sosial seperti WhatsApp Group (Choiriyah, 2021). WhatsApp memiliki berbagai fungsi, di antaranya adalah bisa mengirim pesan, chat grup, berbagi foto, video, dan dokumen (Hutami, 2020).

Indonesia merupakan salah satu negara dengan jumlah kasus terkonfirmasi yang cukup tinggi, yakni hingga tanggal 13 April tercatat sebanyak 1.577.526 kasus. Kalimantan Selatan merupakan provinsi dengan jumlah kasus yang mengalami peningkatan. Kabupaten Banjar termasuk salah satu kabuoaten dengan jumlah kasus COVID-19 yang cukup tinggi dan terus mengalami peningkatan tercata pada tanggal 14 April 2021 sebanyak 102 suspek. (Kemenkes RI, 2021). Kabupaten Banjar memiliki beberapa daerah kecamatan salah 
satunya kecamatan Aluh-Aluh. Kecamatan Aluh-Aluh pernah termasuk ke dalam zona merah pada tahun 2021. Zona merah maksudnya daerah yang sudah mempunyai PDP lebih dari 10 orang, ada kejadian Covid-19 dan ada yang meninggal pada daerah tersebut (Lubis, 2021). Dalam hal ini perlu penanganan lebih serius penyebaran COVID-19 sehingga dapat memutus rantai penularan.

Kegiatan pengabdian ini dilakukan di Kecamatan Aluh-Aluh Desa Aluh-Aluh Besar RT.04. Kegiatan ini dilakukan untuk melihat pengetahuan dan sikap dari remaja putri Desa Aluh-Aluh Besar RT.04. Karena masa remaja merupakan masa transisi dari anak-anak menuju dewasa dimana pada masa ini seseorang memiliki keadaan emosi yang labil dalam menghadapi kondisi yang tidak terduga, misalnya dalam masa pandemi ini mereka merasakan ketakutan dan kecemasan yang berlebihan terhadap penularan virus. Perempuan merupakan sosok yang dianggap lebih sensitif terhadap emosi dibandingkan dengan laki-laki. Jika terjadi sesuatu hal yang tidak wajar terhadap kondisi lingkungannya, maka perempuan akan lebih cepat peka dan merasakan ketidaknyamanan akan hal tersebut (Puspita, 2021).

Salah satu cara untuk meningkatkan pengetahuan dan sikap adalah melalui edukasi. Pengetahuan tentang penyakit Covid-19 merupakan hal yang sangat penting agar tidak menimbulkan peningkatan jumlah kasus penyakit Covid-19. Pengetahuan pasien Covid19 dapat diartikan sebagai hasil tahu dari pasien mengenai penyakitnya, memahami penyakitnya, cara pencegahan, pengobatan dan komplikasinya (Sabarudin, 2020). Sikap juga merujuk pada respon individu pada sesuatu hal, dan respon itu melibatkan pikiran, perasaan, perhatian dan gejala kejiwaan yang lain sikap adalah kesiapan atau kesediaan individu untuk bertindak dan bukan merupakan pelaksanaan motif tertentu. Sikap belum merupakan tindakan atau aktifitas akan tetapi baru merupakan predisposisi sebuah perilaku (Yuhara, 2020).

WHO menyarankan cara pencegahan dengan rajin mencuci tangan dengan sabun pada air yang mengalir, menjaga jarak dari orang saat bicara, jangan menyentuh wajah dengan tangan yang kotor. Juga disarankan untuk memakai masker serta menutup hidung dan mulut dengan tisu atau siku yang tertekuk ketika batuk. Adapun beberapa langkah yang pencegahan penyebaran covid-19 yang disampaikan oleh kementrian kesehatan yaitu : (a) selalu melakukan kebersihan tangan dengan menggunakan handsanitizer ataupun mencuci tangan menggunakan sabun di air mengalir, (b) jangan menyentuh mulut, mata atau hidung, (c) praktikan etika batuk dan bersin utamanya di tempat umum (d) gunakan masker saat keluar rumah, (e) terapkan prinsip jaga jarak (minimal 1 meter) (Kementerian Kesehatan, 2020).

Langkah-langkah preventif yang dilakukan tentunya harus sejalan dengan didukung oleh kontribusi media sosial sebagai edukasi masyarakat tentang Covid-19 di masa pandemi seperti yang terjadi sekarang ini. Melalui media sosial dapat diberikan tindakantindakan untuk mencegah penularan Covid-19. Komunikasi media massa dalam hal ini adalah media sosial, merupakan komponen mendasar dari banyak strategi promosi kesehatan yang dirancang untuk mengubah perilaku risiko kesehatan (Sabarudin, 2020).

Kegiatan pengabdian kepada masyarakat atau program base learning (PBL) bertujuan untuk memberikan edukasi kepada remaja putri di Desa Aluh-Aluh Besar RT.04 yang diselenggarakan melalui Whatsapp group dengan memberikan pemahaman dan memberikan pengetahuan terkait pencegahan COVID-19.

\section{METODE}

Penanggulangan rendahnya pengetahuan mengenai Covid-19 pada remaja putri dilakukan melalui edukasi kesehatan secara online melalui whatsapp group. Sasaran atau target dari kegiatan ini adalah remaja putri yang tinggal di Desa Aluh-Aluh Besar RT 04 Kecamatan Aluh-aluh Kabupaten Banjar dan aktif menggunakan sosial media whatsapp. Remaja putri yang mengikuti kegiatan ini ada sebanyak 14 orang.

Pelaksanaan kegiatan ini dilakukan dengan menggunakan poster elektronik, dan rekaman suara (voice note). Poster elektornik dibuat dengan gambar dan tulisan semenarik mungkin ditambah dengan pemberian rekaman suara (voice note) yang tujuannya untuk mempermudah dalam memahami pesan yang akan disampaikan.

Penyelenggaraan

pengabdian masyarakat ini terdiri dari beberapa tahap diantaranya tahap persiapan, tahap pelaksanaan kegiatan dan monitoring dan evaluasi.

Pada tahap persiapan yang dilakukan oleh tim pelaksana kegiatan adalah mengumpulkan kontak remaja putri agar dimasukan kedalam whatsapp group, penyusunan soal pretest dan posttest, serta pembuatan media untuk penyampaian materi yaitu poster elektronik dan rekaman suara (voice note). 
Pada tahap pelaksanaan kegiatan dimulai dengan melakukan pretest melalui google formulir yang disebarkan melalui whatsapp group, pretest dilakukan untuk mengukur pengetahuan remaja putri mengenai Covid-19 sebelum diberikan materi. Kemudian dilanjutkan dengan pemberian materi dengan mengirimkan poster elektronik dan rekaman suara (voice note) serta dilakukan sesi diskusi setelah remaja putri selesai membaca poster eketronik dan mendengarkan rekaman suara (voice note). Setelah sesi diskusi selesai dilakukan pemberian posttest dengan soal yang sama dengan pretest yang bertujuan untuk mengetahui peningkatan pengetahuan remaja putri mengenai Covid-19 setelah diberikan materi.

Kegiatan monitoring dan evaluasi dilakukan pada saat kegiatan penyuluhan berlangsung dan setelah kegiatan penyuluhan selesai. Monitoring dilakukan dengan cara melakukan pemantauan dan pengawasan terhadap proses, hasil dan dampak dari kegiatan penyuluhan ini. Evaluasi dari program ini dapat dilihat dari meningkatnya pengetahuan sasaran terkait Covid-19 dengan menilai apakah pengetahuan yang telah dimiliki remaja putri dimanfaatkan secara efektif dan efisien dilihat dari hasil pretest dan posttest yang telah diberikan.

\section{HASIL DAN PEMBAHASAN}

Hasil kegiatan memuat karakteristik remaja putri, distribusi frekuensi pengetahuan dan sikap remaja putri mengenai Covid-19. Serta hasil uji statistik untuk melihat perbedaan antara pengetahuan dan sikap sebelum intervensi dan sesudah intervensi.

Berikut adalah karakteristik responden pada kegiatan pemberian edukasi mengenai tablet tambah darah (TTD) dan covid-19.

Tabel 1. Karakteristik Responden

\begin{tabular}{lcc}
\hline Keterangan & Jumlah & Persentase \\
\hline $\begin{array}{l}\text { Jenis } \\
\text { Kelamin }\end{array}$ & & \\
$\begin{array}{l}\text { Perempuan } \\
\text { Usia }\end{array}$ & 14 orang & $100 \%$ \\
$11-15$ tahun & 4 orang & $28,6 \%$ \\
$16-25$ tahun & 10 orang & $71,4 \%$ \\
\hline Total & 14 orang & $100 \%$ \\
\hline $\begin{array}{l}\text { Sumber: Kegiatan PBL II Mahasiswa PSKM FK } \\
\text { ULM Tahun 2020 }\end{array}$
\end{tabular}

Berdasarkan tabel 1 diketahui bahwa seluruh responden berjenis kelamin perempuan yaitu sebanyak 14 orang $(100 \%)$. Usia responden paling banyak berada pada interval 16-21 tahun yaitu sebanyak 10 orang $(71,4 \%)$.

Berikut adalah Distribusi Frekuensi Pengetahuan dan Sikap Remaja Putri Tentang Covid-19 di desa Aluh-Aluh Besar RT. 04.
Tabel 2. Distribusi Frekuensi Pengetahuan dan Sikap Remaja Putri Tentang Covid-19

\begin{tabular}{llcc}
\hline No & Kategori & N & Persentase \\
\hline 1 & $\begin{array}{l}\text { Pengetahuan } \\
\text { Pre-test } \\
\text { Baik }\end{array}$ & $\begin{array}{c}12 \\
\text { orang } \\
2\end{array}$ & $85,7 \%$ \\
& Kurang & $14,3 \%$ \\
& $\begin{array}{c}2 \\
\text { Post-test } \\
\text { Baik }\end{array}$ & $\begin{array}{c}12 \\
\text { orang } \\
\end{array}$ & $85,7 \%$ \\
& Kurang & $\begin{array}{c}2 \\
\text { orang }\end{array}$ & $14,3 \%$ \\
\hline 2 & $\begin{array}{l}\text { Sikap } \\
\text { Pre-test }\end{array}$ & 14 & $100 \%$ \\
& Baik & orang & \\
& $\begin{array}{l}\text { Post-test } \\
\text { Baik }\end{array}$ & 14 & $100 \%$ \\
& & orang & \\
\hline
\end{tabular}

Sumber : Kegiatan PBL II Mahasiswa PSKM FK ULM Tahun 2020

Berdasarkan Tabel 2. dapat diketahui bahwa pengetahuan responden sebelum mendapatkan materi mengenai Covid-19 sebagian besar termasuk dalam kategori baik yaitu sebanyak 12 orang (85,7\%). Pengetahuan responden dengan kategori baik setelah mendapatkan materi mengenai Covid-19 yaitu tetap sebanyak 12 orang $(85,7 \%)$. Berdasarkan hasil tersebut diketahui bahwa sebian besar remaja putri memiliki pengetahuan yang baik mengenai Covid-19 namun tidak terdapat peningkatan pengetahuan sebelum mendapatkan materi dan setelah mendapatkan materi.

Sikap responden sebelum mendapatkan materi dan sesudah mendapatkan materi mengenai Covid-19 seluruhnya memiliki sikap yang baik yaitu 14 orang $(100 \%)$.

Tabel 3. Hasil Uji Statistik Pengetahuan Remaja Putri Tentang Covid-19

\begin{tabular}{|c|c|c|c|c|}
\hline $\begin{array}{l}\text { Jeni } \\
\text { S } \\
\text { Tes }\end{array}$ & $\mathbf{N}$ & $\begin{array}{l}\text { Rata } \\
\text {-rata }\end{array}$ & $\begin{array}{c}\text { Uji } \\
\underset{s}{\text { Normalita }}\end{array}$ & $\begin{array}{c}\text { Uji Beda } \\
\text { Rata-rata } \\
\text { (Uji } \\
\text { Wilcoxon } \\
\text { ) }\end{array}$ \\
\hline $\begin{array}{l}\text { Pre- } \\
\text { test }\end{array}$ & $\begin{array}{l}1 \\
4\end{array}$ & $\begin{array}{c}77,3 \\
8\end{array}$ & $\begin{array}{c}0,001< \\
0,05\end{array}$ & $\begin{array}{l}\text { Nilai Sig } \\
(0,016)<\end{array}$ \\
\hline $\begin{array}{l}\text { Post- } \\
\text { test }\end{array}$ & $\begin{array}{l}1 \\
4\end{array}$ & $\begin{array}{c}86,3 \\
1\end{array}$ & $\begin{array}{c}0,042< \\
0,05\end{array}$ & 0,05 \\
\hline
\end{tabular}

Berdasarkan Tabel 3. diketahui bahwa baik nilai pre-test maupun post-test responden tidak berdistribusi normal karena nilai 
signifikansi yang kurang dari 0,05. Sehingga pengujian dilakukan dengan uji wilcoxon. Terlihat pada uji wilcoxon nilai Sig $(0,016)<$ 0,05 berarti Ho ditolak yang artinya ada perbedaan yang signifikan antara pengetahuan remaja putri Desa Aluh-Aluh Besar RT. 04 pada saat pengisian kuesioner sebelum dan sesudah penyuluhan. Hal ini dapat terjadi karena pada saat penyuluhan, tim memberikan materi yang mudah dimengerti oleh remaja putri, dan remaja putri yang antusias dalam membaca soft file poster yang dibagikan dan voice note yang menjelaskan mengenai Covid-19 melalui whatsapp group.

Berdasarkan penelitian yang dilakukan oleh Siregar IA et al (2019) bahwa pengetahuan berpengaruh terhadap perilaku pencegahan penyakit. Menururt Notoadmodjo (2010) dikutip dalam Siregar IA dkk (2019) bahwa pengetahuan adalah hasil dari tahu dan ini terjadi setelah orang melakukan penginderaan terhadap suatu objek tertentu. Penginderaan terjadi melalui panca indera penglihatan, pendengaran, penciuman, rasa dan raba. Sebagian besar pengetahuan manusia diperoleh melalui mata dan telinga. Peningkatan pengetahuan melalui pendidikan kesehatan akan menghasilkan perubahan atau peningkatan pengetahuan masyarakat. Akhirnya pengetahuan tersebut diharapkan berpengaruh terhadap perilaku seseorang untuk menjadi lebih baik dalam menjaga kesehatan (Siregar IA, 2019)

Berdasarkan penelitian Maodu (2020) didapatkan hasil sebanyak $17,9 \%$ responden yang berpengetahuan baik memiliki tindakan yang baik mengenai covid-19 (82,1\%). Hasil uji statistik menunjukan terdapat hubungan yang signifikan antara pengetahuan individu dengan tindakan individu mengenai COVID-19 $(p=0,000<0,05)$. Individu dengan pengetahuan tidak baik mempunyai risiko untuk memiliki tindakan yang tidak baik sebesar 6,674 kali dibandingkan individu dengan pengetahuan baik (Syakurah R, 2020).

Tabel 4. Hasil Uji Statistik Sikap Remaja Putri Tentang Covid-19

\begin{tabular}{|c|c|c|c|c|}
\hline $\begin{array}{l}\text { Jenis } \\
\text { Tes }\end{array}$ & $\mathbf{N}$ & $\begin{array}{l}\text { Rata- } \\
\text { rata }\end{array}$ & $\begin{array}{c}\text { Uji } \\
\text { Normalitas }\end{array}$ & $\begin{array}{c}\text { Uji } \\
\text { Beda } \\
\text { Rata- } \\
\text { rata } \\
\text { (Uji T) }\end{array}$ \\
\hline $\begin{array}{l}\text { Pre- } \\
\text { test }\end{array}$ & 14 & 83,92 & $\begin{array}{c}0,058< \\
0,05\end{array}$ & \multirow{2}{*}{$\begin{array}{c}\text { Nilai } \\
\text { Sig } \\
(0,003) \\
<0,05\end{array}$} \\
\hline $\begin{array}{l}\text { Post- } \\
\text { test }\end{array}$ & 14 & 87,26 & $\begin{array}{c}0,351< \\
0,05\end{array}$ & \\
\hline
\end{tabular}

Sumber : Kegiatan PBL II Mahasiswa PSKM FK ULM Tahun 2020
Berdasarkan Tabel 4. diketahui bahwa baik nilai pre-test maupun post-test responden berdistribusi normal karena nilai signifikansi yang lebih dari 0,05 . Sehingga pengujian dilakukan dengan uji T (Paired sample $t$ test). Terlihat pada uji T nilai Sig $(0,003)<0,05$ berarti Ho ditolak yang artinya ada perbedaan antara sikap remaja putri di Desa Aluh-Aluh Besar RT. 04 pada saat pengisian kuesioner sebelum dan sesudah penyuluhan.

Teori Notoatmodjo (2014) menyebutkan bahwa sikap merupakan konsep yang sangat penting dalam komponen sosio-psikologis, karena merupakan kecenderungan bertindak, dan berpersepsi. Menurut Azwar (2012) Faktorfaktor yang mempengaruhi sikap Media elektronik ataupun cetak sangat berpengaruh kepada terbentuknya pendapat dan kepercayaan seseorang. pemberian informasi dengan media masa mengenai sesuatu hal dapat melandasi kognitif baru terbentuknya sikap. Sikap yang baik atau mendukung akan memudahkan seseorang dalam melakukan sebuah tindakan, terutama pada pandemi Covid-19 apabila seseorang memiliki pengetahuan dan sikap yang baik mengenai Covid-19, maka dapat melakukan tindakan yang baik mengenai pencegahan Covid-19 (Suprayitno E, 2020). Hal ini sejalan dengan penelitian yang dilakukan Nismawati (2020) Sikap setuju dengan menerapkan protokol kesehatan sebanyak $67,9 \%$ sedangkan sikap tidak setuju dengan menerapkan protokol kesehatan sebanyak $16,0 \%$. Hasil analisis statistis diperoleh nilai $\mathrm{p}(0,000)<0,05$ maka $\mathrm{HO}$ ditolak, yang artinya terdapat hubungan antara sikap dengan perilaku penerapan protokol kesehatan (Nismawati, 2020).

$\mathrm{Hal}$ ini bertentangan dengan penelitian Yuhara (2020) rata-rata sikap responden sebelum mendapatkan materi edukasi adalah sebesar 86,42 dan sesudah diberi materi edukasi meningkat sebanyak $7,15 \quad(7,64 \%)$ menjadi 93,57. Rata-rata sikap pada hasil pengukuran ini termasuk dalam kategori positif. Meskipun terdapat penambahan skor rata-rata sikap, hasil peningkatan sikap kearah yang lebih positif pada hasil pengukuran ini tidak signifikan $(p>0,05)$ (Yuhara NA, 2020).

\section{SIMPULAN DAN SARAN Simpulan}

Sebagian besar remaja putri memiliki pengetahuan yang baik mengenai Covid-19, namun tidak terdapat peningkatan pengetahuan antara sebelum mendapatkan materi dan setelah mendapatkan materi. Pada uji statistik dengan uji Wilcoxon nilai Sig $(0,016)$ bahwa ada perbedaan yang signifikan antara pengetahuan remaja putri Desa Aluh-Aluh 
Besar RT. 04 pada saat pengisian kuesioner sebelum dan sesudah penyuluhan. Dilihat dari sikap, sikap remaja putri sebelum mendapatkan materi dan sesudah mendapatkan materi mengenai Covid-19 seluruhnya memiliki sikap yang baik. Dari hasil uji T (Paired sample t test) dengan nilai Sig $(0,003)$ diketahui ada perbedaan antara sikap remaja putri di Desa Aluh-Aluh Besar RT. 04 pada saat pengisian kuesioner sebelum dan sesudah penyuluhan.

\section{Saran}

Perlu adanya sosialisasi serta promosi mengenai pencegahan Covid-19 oleh pihak Puskesmas yang ada di Desa Aluh-Aluh Besar. Selain itu perlu dilakukan penyuluhan lanjutan mengenai penerapan protokol kesehatan selama situasi Covid-19 agar masyarakat dapat meningkatkan perilaku dalam pencegahan Covid-19.

\section{UCAPAN TERIMAKASIH}

Terima kasih kepada kepala Desa Aluh-Aluh Besar dan Ketua RT. 04 yang telah membantu dalam kegiatan ini, serta kepada dosen pembimbing dan rekan sejawat yang telah membantu dalam pelaksanaan kegiatan ini sehingga kegiatan ini dapat berjalan lancar sesuai dengan yang diharapkan

\section{DAFTAR RUJUKAN}

Choiriyah NA, dkk. (2021). Penyuluhan Pencegahan Penularan COVID-19 di Lingkungan Kantor dan Pembuatan Lemongrass Coolant melalui Live Zoom. Jurnal ABDIMAS: Jurnal Pengabdian Masyarakat Universitas Merdeka Malang 6(1): 18-26. https://doi.org/10.26905/abdimas.v6i1.48 65

Hutami MS, Anindiya SN. (2020). Metode Pembelajaran Melalui Whatsapp Group Sebagai Antisipasi Penyebaran Covid-19 pada AUD di TK ABA Kleco Kotagede. Jurnal PAUDIA 9(1): 126-130. https://doi.org/10.26877/paudia.v9i1.610 7

Kementrian Kesehatan. (2020). Pedoman COVID REV-4. Pedoman Pencegahan Dan Pengendalian Coronavirus Disease (COVID-19), 1(Revisi ke-4), 1-125.

Kemenkes. (2021). Situasi terkini perkembangan Novel Coronavirus (COVID-19).

https://infeksiemerging.kemkes.go.id/situ asi-infeksi-emerging/situasi-terkiniperkembangan-coronavirus-diseasecovid-19-14-april-2021
Lubis R, Jemadi, Rasmaliah. (2021). Educate cadres for the prevention of Covid-19 in Sei Mati Village, Medan Maimun District. Jurnal Abdimas Talenta 6(1): 154-160. https://doi.org/10.32734/abdimastalenta. v6i1.5322

Nismawati, Marhtyni. (2020). Faktor yang berhubungan dengan penerapan protokol kesehatan pada pelaku usaha mikro selama masa pandemi Covid -19. UNM Environmental Journals 3(3):116124.

https://doi.org/10.26858/uej.v3i3.16210

Puspita IM, Annisa WR, A'im MN. (2021). Gambaran kecemasan dan kepatuhan remaja putri terhadap kebiasaan baru pada masa pandemi covid-19 di Surabaya. Journal of Midwirefy Science 5(1): 52-61. https://doi.org/10.36341/jomis.v5i1.1492

Sabarudin, dkk. (2020). Efektivitas Pemberian Edukasi secara Online melalui Media Video dan Leaflet terhadap Tingkat Pengetahuan Pencegahan Covid-19 di Kota Baubau. Jurnal Farmasi Galenika 6(2): 309-318. https://doi.org/10.22487/j24428744.2020 .$v 6.12 .15253$

Siregar IA, Siagan M, Wau H. (2019). Hubungan pengetahuan dan sikap dengan tindakan pencegahan penyakit infeksi menular seksual pada anak buah kapal di pelabuhan Belawan. Jurnal Kebidanan Kestra 2(1): 1-8). https://doi.org/10.35451/jkk.v2i1.231

Suprayitno E, dkk. (2020) Pengetahuan dan sikap masyarakat dalam pencegahan Covid-19. Jurnal IImu Kesehatan 5(2): 22-

27. https://doi.org/10.24929/jik.v5i2.1123

Syakurah R, Maodu J. (2020). Pengetahuan terkait Usaha Pencegahan Coronavirus Disease (COVID-19) di Indonesia. Higeia Journal Of Public Healthresearch And Development 4(3): 333-346. https://doi.org/10.15294/higeia.v4i3.3784 4

Yuhara NA, Ellsya AR, Sarah PA. (2020). Pengetahuan dan sikap masyarakat terhadap penggunaan obat tradisional/herbal dalam pencegahan COVID-19. Yogyakarta: UII Press. 